\title{
MEMAHAMI LOGIKA PEMROGRAMAN KOMPUTER PERANTARA ALGORITMA
}

Oleh : Annizar m.sinulingga

PMM FITK UINSU

annizarmalemsinulingga@gmail.com

\begin{abstract}
ABSTRAK
Algoritma dam pemrograman adalah mamteri perkuliahan yang menuntut kita untuk berpikir kritis ketiks menyelesaikan masalah-masalah yang terjadi dalam computer dengan singkat,cepat dan akurat. Disusun secara logis ketika perangkat computer diberikan instruksi untuk menyelesaikan sebuah masalah yang dapat diselesaikan dengan baik dan cepat. algoritma dapat menyederhanakan program. jadi program adalahimplementasi algoritma yang tertulis dalam bahasa pemrograman tertentu hingga dapat dilakukan oleh perangkat computer.
\end{abstract}

KATA KUNCI : Algoritma,bahasa pemrograman,komputer Pseudocode, flowchart 


\section{PENDAHULUAN}

Pemakaian komputer sangat pesat sejalan dengan teknologi dari computer sendiri.Dimanfaatkan diberbagai bidang contohnya dibidang industry, perdagangan, pendidikan, pemerintahan, ilmu pengetahuan eksakta juga social budaya. Komputer merupakan sebuah alat yang sangat canggih dengan serangkaian perintah manusia untuk menyelesaikan sebuah permasalahan yang muncul secara cepat, tepat, akurat. penyelesaian masalah disebut dengan program,agar program dapat diselesaikan harus menggunakan bahasa yang dapat dipahami oleh komputer yang disebut dengan bahasa pemrograman. Pemrograman adalah proses mengimplementasikan algoritma dengan suatu bahasa pemrograman (Budi,2000:21.Algoritma dan pemrograman merupakan jantung pembelajaran teknik informatika. Sejarah kata algoritma berasal dari Abu Ja'far Mohammed Ibn Musa alKhowarizmi, ilmuan Persia yang menulis kitab al jabr w'al-muqabala (rules of restoration and reduction) sekitar tahun 825 M dari ahli matematika.al-khuwarizmi dibaca oleh orang barat menjadi Algorism.Perubahan kata algorism menjadi algorithm karena kata algorism sering dikelirukan dengan kata arithmetic sehingga akhiran -sm mrenjadi -thm.Lambat laun kata algorithm dipakai sebagai metode perhitungan (komputasi secara umum),sehingga kehilangan makna aslinya.Dalam bahasa Indonesia algorithm diserap menjadi algoritme.Defenisi algoritme adalah susunan langkah-langkah sistematis dan logis dalam pemecahan suatu masalah. ). algoritma merupakan deret instruksi jelas digunakan untuk memecahkan masalah, memperoleh iuran dari masukan dengan jumlah yang terbatas.secara mendalam. Algoritma dapat diterapkan disetiap permasalahan yang akan dipecahkan atau diselesaikan, dengan meneliti hasil perolehan ilmu pengetahuan juga respon yang diberikan oleh mahasiswa terhadap algoritma pemrograman. maka penulis memiliki ide membuat judul memahami algoritma.penulisan Artikel ini dilatarbelakangi dengan tugas yang diberikan kepada penulis sekaligus untuk menambah wawasan pengetahuan penulis juga pembaca mengenai materi yang tertera dalam artikel. Manfaat yang dapat diperoleh dari artikel ini sebagai berikut:

1.Memberikan informasi pentingnya algoritma pada pembelajaran algoritma pemrograman

2.mempermudah proses pembelajaran algoritma pemrograman

3.Dapat dijadikan sebagai bahan pertimbangan untuk mengkaji lebih dalam algoritma pemrograman serta penerapannya disetiap programman computer. 


\section{STUDI LITERATURE}

\section{Pemrograman}

Pemrograman memiliki tujuan memuat program untuk melakukan perhitungan sesuai dengan keinginan juga kebutuhan dari programer.Dalam penggunaan pemrograman dibutuhkan keterampilan dalam algoritma, logika,juga bahasa pemrograman. Berdasarkan pendapat Sutedjo 2000:21 pemrograman ialah suatu proses mengimplementasikan algoritma menggunakan sebuah bahasa pemrograman. pemrograman dapat juga diartikan proses menulis,menguji, memperbaiki juga memelihara untuk membangun program komputer yang tertulis dalam bentuk bahasa pemrograman.Dengan demikian dapat disimpulkan pemrograman adalah sebuah seni dengan menggunakan algoritma yang berhubungan erat dengan bahasa pemrograman sehingga terbentuk sebuah program komputer. Dalam bahasa pemrograman gaya pemrograman nya berbagai jenis, berbeda Pemrograman mendukung gaya pemrograman yang berbeda jua.Untuk gaya pemrograman sering disebut atau dikenal dengan paradigma pemrograman.menurut Rinaldi (2007:4) algoritma merupakan urutan langkahlangkah untuk memecahkan masalah sedangkan Menurut Levitin algoritma merupakan deretan instruksi yang jelas untuk memecahkan masalah,yaitu memperoleh keluaran yang diinginkan dari suatu masukkan dalam jumlah yang terbatas.

\section{Algoritma}

Berdasarkan Kamus besar bahasa Indonesia (KBBI) yang diterbitkan Balai pustaka pada tahun 1988, Algoritma merupakan urutan logis pengambilan keputusan dalam pemecahan sebuah masalah.Sejarah algoritma bermula pada abad ke-9,Buku mengenai algoritma karangan Muhammad bin Musa al-khawarizmi.Seiring waktu berjalan pada tahun 1360-an Algoritma mulai diterapkan dalam menyelesaikan masalah komputasi serta matematis ini merupakan awal bermunculan logaritma.pada tahun 1684, algoritma digunakan secara luas untuk menyelesaikan permasalahan kalkulus.Kemudian ditahun 1759 algoritma diakui sebagai sebuah metode yang dipergunakan menyelesaikan masalah Selanjutnya ditahun 1950 algoritma akrab dengan komputer dan Al.sehingga tercipta sebuah mesin pertama yang dipergunakan menjawab problem geometrik dengan bahasa pemrograman juga informasi tertentu pada tahun 1956.Ditahun itu juga para peneliti menguji potensi komputer yang diprogram dengan bahasa untuk menyelesaikan masalah sehari-hari secara serius.Logis sebuah kata kunci dalam algoritma.Algoritma adalah urutan atau langkah-langkah untuk menyelesaikan masalah bersifat secara logis dan sistematis.pertimbanganyang diperlukan dalam pemilihan algoritma yang pertama algoritma harus benar, maksudnya memberikan solusi yang diinginkan menurut beberapa masukan yang ada dari sebuah permasalahan.Tidak penting sebagus bagaimana algoritma jika memberikan solusi yang salah dapat dipastikan bukan sebuah algoritma yang baik.Kedua yaitu algoritma yang baik pasti mampu menghasilkan hasil yang sedekat mungkin dengan nilai sebenarnya.sudah seharusnya kita mengetahui seberapa baik hasilnya yang akan 
dicapai sebuah algoritma.Algoritma menyelesaikan masalah yang memerlukan aproksimasi hasil artinya menyelesaikan masalah yang hasilnya berupa pendekatan. Ketiga yakni efisiensi pada algoritma, misalnya algoritma sudah mendekati kebenarannya namun memakan waktu yang terulur maka tidak akan dipakai dikarenakan inti daripada algoritma ialah algoritma yang baik dan mendapatkan solusi ataupun jawaban kebenaran dengan cepat, tepat,dan akurat.

\section{Struktur algoritma}

\section{Sekuensial (Runtunan)}

struktur program yang dikerjakan secara urut dari awal higga akhir.penulisannya dari atas ke bawah.

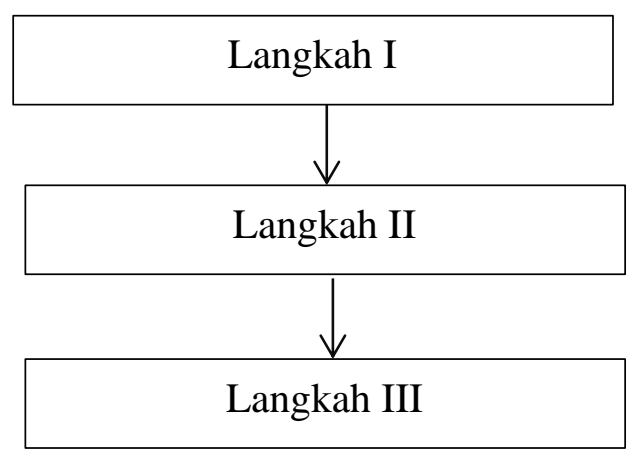

2.sturuktur seleksi

Struktur seleksi atau pemilihan yakni proses menyeleksi kondisi yang terdapat pada struktur kegiatan yang dikerjakan guna untuk mengambil sebuah keputusan untuk alternative yang tersedia

\section{Struktur perulangan}

struktur pengulangan yakni kemampuan untuk melakukan sebuah pekerjaan yang sama secara berulang-ulang.komputer merupakan sebuah alat yang tak kenal lelah. untuk struktur pengulangan disebut loop kemudian algoritma yang di ulang disebut aksi.

\section{4. logika dan Algoritma}

Secara bahasa logika berasal dari Yunani yakni Logos mengartikan ilmu.logika adalah ilmu yang mengajarkan bagaimana cara berpikir secara kritis untuk bisa melakukan sesuatu mencapai tujuan yang pasti.

Menurut Barakbah(2013:1), Algoritma sangat akrab dengan logika,yakni kemampuan seseorang dalam hal berpikir denga menggunakan akal mengenai sebuah persoalan yang harus menghasilkan kebenaran terbukti dan dapat diterima oleh akal.Logika sering kali di kaitkan dengan kecerdasan pada seseorang. Biasanya seseorang yang mampu memperalat logikanya nyaris disebut orang-orang yang cerdas.Logika sangat identik dengan itu akal juga penalaran.Dimana penalaran berupa bentuk pemikiran.Pemikiran ialah Pengetahuan secara tidak langsung berdasakan pernyataan langsung.Pemikiran secara mutlak tidak lah selalu benar tetapi dapat juga benar namun juga salah.Simpulan dari definisi logika adalah sebuah ilmu yang mengajarkan juga mengarahkan cara berpikir ketika melakukan suatu kegiatan yang memiliki tujuan pasti dan sangat terkait erat dengan algoritma.Dengan belajar logika menumbuhkan prinsip-prinsip dalam diri seseorang sehingga dapat berpikir secara valid dan menimbulkan kesadaran agar mempergunakan prinsip-prinsip yang ada secara sistematis.Dalam keseharian jika kita 
amati sebenarnya kita sudah menggunakan

kaidah-kaidah yang ada pada algoritma

\section{Beda Algoritma dengan Pemrograman}

Bahasa pemrograman sangat berkaitan secara erat dengan algoritma.Jika disatukan dengan pemrograman maka algoritma dalam pembuatannya harus memerhatikan:

1. Penulisan algoritma harus seimbang antara bahasa pemrograman dengan yang memproses yang disebut komputer.

2. Dalam berbagai bahasa pemrograman hasil terjemahan dari notasi

3. Untuk hasil keluaran akan tetap sama walaupun banyak bahasa pemrogramannya dikarenakan oleh algoritma yang sama

Algoritma digunakan sebagai pembantu untuk mengkonversikan sebuah permasalahan kedalam bahasa pemrograman. Menurut Ridho (2013 : 7) algoritma adalah hasil pemikiran yang sudah terkonsep dan dilakukan oleh sebuah alat yaitu computer dan hal yang paling penting algoritma harus selalu diubah kedalam bahasa pemrograman agar dapat diproses. Kita dapat simpulkan bahwa program adalah implementasi sebuah algoritma yang tertulis dalam bahasa pemrograman yang dilakukan oleh computer. Biasanya kegiatan seperti ini disebut dengan pemrograman (programmer) kemudian dalam menjalankannya computer terdapat langkah langkah instruksi yang secara otomatis operasi-operasi yang berada dalam computer akan menyesuaikan.

\section{PEMBAHASAN}

\section{Algoritme dan pemrograman}

Algoritma adalah urutan atau langkahlangkah untuk menyelesaikan masalah bersifat secara logis dan sistematis.pertimbanganyang diperlukan dalam pemilihan algoritma yang pertama algoritma harus benar, maksudnya memberikan solusi yang diinginkan menurut beberapa masukan yang ada dari sebuah permasalahan.Tidak penting sebagus bagaimana algoritma jika memberikan solusi yang salah dapat dipastikan bukan sebuah algoritma yang baik.Kedua yaitu algoritma yang baik pasti mampu menghasilkan hasil yang sedekat mungkin dengan nilai sebenarnya.sudah seharusnya kita mengetahui seberapa baik hasilnya yang akan dicapai sebuah algoritma.Algoritma menyelesaikan masalah yang memerlukan aproksimasi hasil artinya menyelesaikan masalah yang hasilnya berupa pendekatan. Ketiga yakni efisiensi pada algoritma, misalnya algoritma sudah mendekati kebenarannya namun memakan waktu yang terulur maka tidak akan dipakai dikarenakan inti daripada algoritma ialah algoritma yang baik dan mendapatkan solusi ataupun jawaban kebenaran dengan cepat, tepat,dan akurat.

Belajar memprogram diartikan belajar memahami metodologi memecahkan masalah,yang tertulis dalam bentuk algoritma.Sedangkan belajar bahasa pemrograman adalah belajar untuk 
menggunakan bahasa pemrograman yang bentuknya instruksi dan juga aturan sintaks. Tujuan dari bahasa pemrograman ada dua kelompok yaitu :

a. Bertujuan umum,dapat digunakan untuk berbagai tujuan,sebagai contoh pascal,visual basic,juga visual $\mathrm{C}++$

b. Bertujuan khusus,bahasa pemrograman yang lebih spesifik yang digunakan untuk tujuan yang sudah di tentukan contohnya seperti matlab dan SQL

Bahasa pemrograman menurut tingkatannya:

1. Bahasa mesin adalah bahasa yang berjalan oleh aturan dari computer itu sendiri.Tersusun dari rangkaian bilangan biner,yakni bilangan 0 dan 1

2. Bahasa asembli yaitu bahasa yang tingkatannya sedikit diaatas bahasa mesin.Dalam bahasa ini menggunakan bahasa yang lebih sederhana,misalnya MOV,ADD,atau STR.Bahasa ini lebih mudah untuk dimengerti oleh computer.Tetapi bahasa ini perlu diterjemahkan kepada bahasa mesin dan orang yang melakukan hal ini disebut dengan assembler.

3. Bahasa tingkat tinggi yakni bahasa yang menggunakan instruksi seperti kata-kata yang persis seperti bahasa keseharian (bahasa sehari-hari).Dalam bahasa ini juga harus diterjemahkan kedalam bahasa mesin dengan alat compiler.misalnya pascal,fortran, dan matlab.

Algoritma yaitu independen bahasa pemrograman tertentu.algoritma yang sudah tersedia tidak boleh hanya bisa diterapkan dalam bahasa pemrograman.untuk penulisan algoritma tidak terikat dalam sebuah aturan tertentu tetapi untuk langkah-langkah yang digunakan harus jelas.

\section{Format penulisan Algoritme}

Dibagi menjadi beberapa bagian diantaranya:

\section{Kalimat deskriptif}

Algoritma yang tertulis dalam bahasa yang sederhana yaitu bahasa seharihari yang berbentuk kalimat.untuk langkah-langkah penyusunan algoritma diterangkan dalam bentuk kalimat.Contoh menentukan nilai maksimal dari sebuah deret bilangan: Algoritma menentukan nilai maksimal dari 70,80,dan 90

1.memerintah computer untuk mengimput 3 nilai dari user yakni 70,80 dan 90

2.Jika 90 adalah nilai paling besar dari 70 maupun 80 maka 90 adalah nilai paling besar

3.Apabila tidak nilai 90 lebih besar dari 70 dan 80 berarti nilai 90 bukanlah nilai terbesar.kemungkinan ada nilai 70 dan nilai 80 .jika 80 lebih besar dari 90 maka 80 nilai terbesar.begitu juga sebaliknya jika nilai 80 tidak lebih besar dari 90,maka nilai 90 yang paling besar 4.selesai

\section{Pseudo}

Imitasi dan kode yang berhubungan dengan instruksi yang tertulis dalam bentuk bahasa computer (bahasa pemrograman). secara umum pseudocode adalah tiruan bahasa pemrograman.pada dasarnya, 
pseudocode adalah yang membantu programmer dalam memikirkan bagaimana pemecahan masalah tanpa berpacu pada syntax yang berasal dari bahasa pemrograman tertentu.Dalam pseudocode tidak memiliki aturan dalam penulisan syntax.pseudocode digunakan menggambarkan logika langkah-langkah program tanpa melihat bahasa pemrogramannya.Namun agar pembaca lebih mudah untuk mempelajari algoritmaalgoritma yang sudah tertulis diberikan sedikit aturan dalam penulisan syntax. Namun aturan dibuat sederhana mungkin agar tidak ada kendala bagi pembaca dalam memahami algoritma-algoritma. Contoh diketahui alas sebuah segitiga $25 \mathrm{~cm}$ dan tingginya $30 \mathrm{~cm}$. Tentukan luas segitiga dengan mengggunakan pseudocode!

Program menghitung_luas_sebbuah segitiga

Deklarasi

Luas, alas, tinggi : integer

Algoritma:

Alas ; 25

Tinggi : 30

Luas $: \frac{1}{2} *$ alas $*$ tinggi

Write (luas)

Agar sebuah algoritma dalam bentuk pseudocode mudah untuk dipahami perlu ditulidkan secara terstruktur.struktur dari algoritma secara pseudocode diantaranya:
- Header (bagian kepala) yaitu bagian yang terdiri dari nama algoritma serta penjelasan algoritma dalam pemberian nama algoritma mengacu terhadap aturan pemberian nama pengenal.Nama algoritma hendaknya singkat,padat,dan akurat.Berisi penjelasan mengenai aktivitas yang dilakukan algoritma secara singkat

- Bagian deklarasi merupakan semua nama pengenal dalam algoritma dapat berupa tatapan ( kostant),peubah ( variabel ), nama tipe,nama prosedur,juga nama fungsi.

- Bagian deskripsi merupakan langkah - langkah penyelesaian masalah berupa intruksi baca data, tampilkan, ulangi, dan sebagainya.

\section{Flowchart}

Menggambarkan langkah-langkah penyelesaian masalah mengunakan kata-kata (kalimat). Namun dalam penyusunan algoritma sangat terpengaruh tata bahasa yang membuat, sehingga terjadi kesulitan bagi pembaca dan kendala dalam memahaminya. Oleh karena itu dalam pembuatan langkah-langkahnya dikembangkann metode yang menggambarkan secara lebih sederhana agar mudah dimengerti, dipahami, mudah digunkaan, dan standart. Penulisan symbol mengunakan flowchart. Flowchart ada dua jenis yakni :

1).Flowchart program bagan alir dimana suatu bagan menggambarkan arus logika dari 
data yang hendak diproses dari awal hingga selesai. Sebuah alat yang digunakan programmer mempersiapkan program yang sulit, terdiri dari simbol-simbol yang sudah mewakili fungsifungsi dari program yang akan dikerjakan :

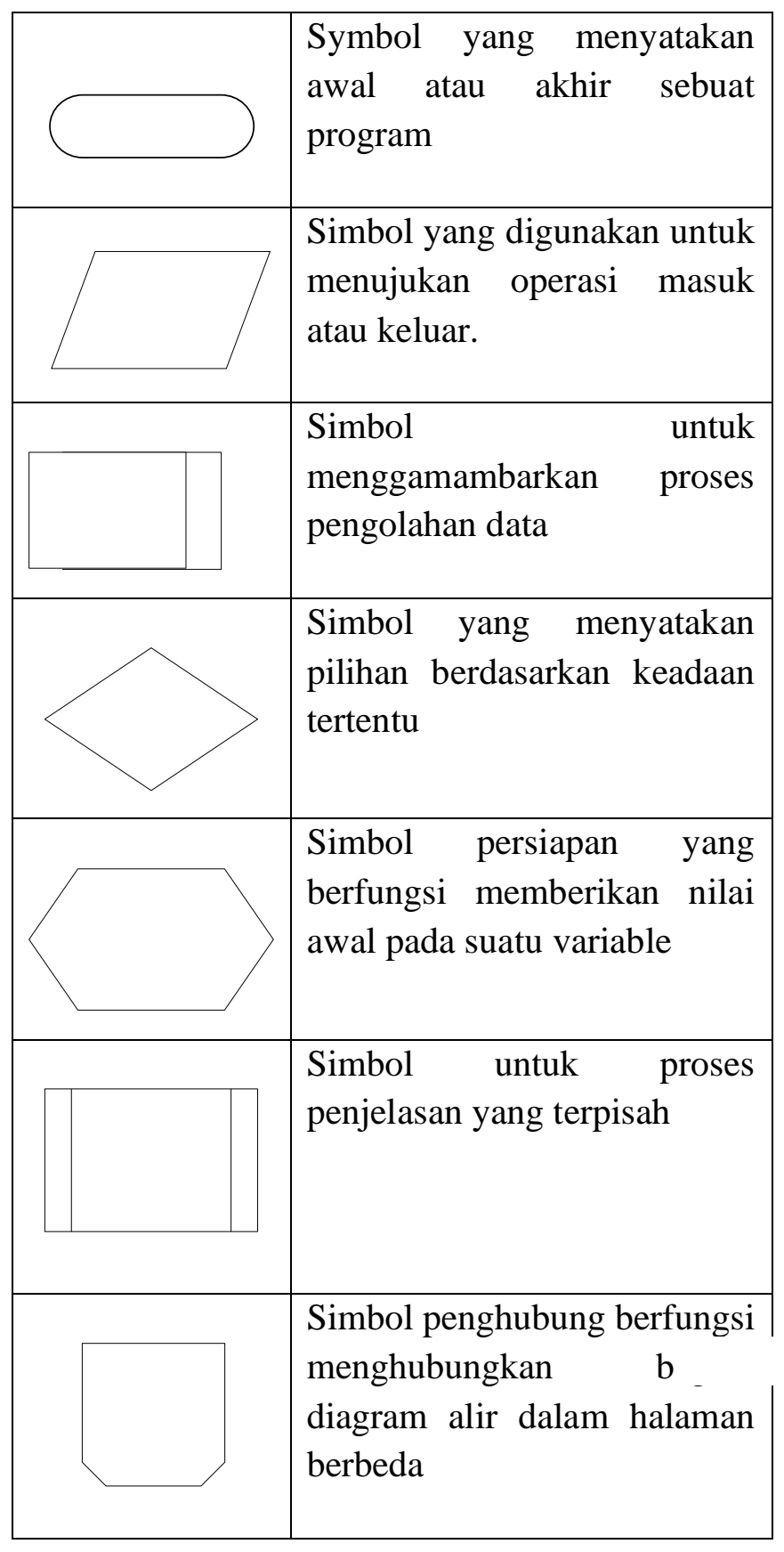

\begin{tabular}{|l|l|}
\hline & $\begin{array}{l}\text { Simbol penghubung terhadap } \\
\text { halaman yang sama } \\
\text { menghubungkan diagram alir } \\
\text { dalam halaman yang sama }\end{array}$ \\
\hline$\downarrow \longrightarrow$ & $\begin{array}{l}\text { Simbol arah berfungsi } \\
\text { menujukan arah aliran proses }\end{array}$ \\
\hline
\end{tabular}

Contoh flowchart sederhana menghitung keliling lingkaran :

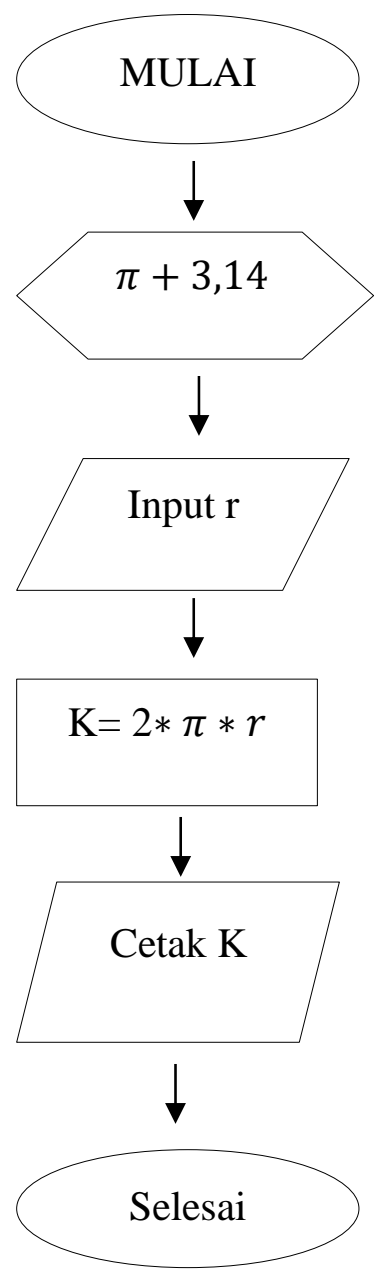

Pedoman untuk membuat flowchart: 
a. Dibuat mulai dari atas menuju kebawah dan dimulai dari bagian kiri halamannya.

b. Kegiatan atau aktifitas yang dilakukan harus ditunjukan dengan jelas.

c. Harus jelas bermula darimana hingga berakkhir.

d. Kegiatan yang ada digunakan kata yang mewakili aktifitas

e. Kegiatan harus sesuai urutannya

f. Kegiatan yang misalnya terpotong dihubungkan dengan symbol penghubung.

g. Simbol-simbol yang dibuat dalam flowchart ialah simbol-simbol standart

2).Flowchart system bagan alir system ada perbedaaan dengan bagan alir program dimana bagan alir program lebih terperinci mengenai langkah-langkah proses dari awal hingga akhir.bagan alir system menggambarkan arus data.simbol symbol yang digunakan dalam bagan alir program ada yang sama dan ada yang berbeda.

Dalam algoritma tahap-tahap menyelesaikan masalah berupa struktur urut,struktur pemilihan,dan struktur pengulangan.dengan tiga langkah ini dapat membentuk konstruksi algoritma.

\section{Persyaratan Algoritme yang baik}

- Algoritma komputer harus efisien dimana proses dapat diselesaikan secepat mungkin dengan frekuensi perhitungan sesingkat mungkin. Dengan kata lain, tidak boros sumber daya.

- Algoritma yang baik harus mudah diimplementasikan ke dalam perangkat komputer.

- Program algoritma yang baik harus mudah dipahami. Ini berlaku non-diskriminatif di mana siapa pun dapat dengan mudah memahami algoritme. Efek buruk dari sulitnya memahami suatu algoritma adalah sulitnya mengelola algoritma tersebut.

- Akurasi tinggi merupakan persyaratan lain dari program algoritma yang baik. Mana bisa menjadi algoritma yang digunakan secara profesional jika hasilnya tidak akurat.

- Semakin umum semakin baik. Algoritma yang baik adalah yang diterima secara umum dan tidak terbatas pada satu bidang tertentu. Jika diterima secara umum, maka algoritma tersebut mampu menyelesaikan masalah dan berguna dalam berbagai bidang.

- Algoritma dan pemrograman yang baik memiliki langkah-langkah yang jelas dan rinci. Setiap proses tepat dan lengkap yang tidak tanggung-tanggung, penuh kejelasan, dan penuh kepastian.

- Algoritma yang baik juga harus dikembangkan. Bukan tidak mungkin suatu algoritma yang terlihat sederhana dapat terus dikembangkan untuk menghasilkan hasil yang lebih tinggi dan lebih baik lagi. 


\section{Cara kerja Algoritme}

Komputer hanya memiliki satu prosesor. Untuk dapat dieksekusi oleh komputer, suatu algoritma harus ditulis dalam notasi bahasa pemrograman, sehingga disebut program. Jadi program adalah pesrwujudan teknis atau implementasi dari suatu algoritma yang ditulis dalam bahasa pemrograman tertentu sehingga dapat dieksekusi oleh komputer. Kata "algoritma" dan "program" sering digunakan secara bergantian.

Misalnya, seseorang mungkin mengatakan sesuatu seperti ini: "Program pengurutan data menggunakan algoritme pengurutan yang dipilih". Atau pertanyaan seperti ini: "Bagaimana algoritma dan program menggambarkan grafik?". Jika Anda sudah mengetahui arti dari algoritma yang disebutkan sebelumnya, Anda dapat membedakan arti dari kata algoritma dan program. Algoritma adalah prosedur untuk memecahkan suatu masalah, sedangkan program adalah implementasi dari algoritma dalam bahasa pemrograman.

Program ditulis dalam salah satu bahasa pemrograman dan tugas membuat program disebut pemrograman. Orang yang menulis program disebut programmer. Setiap langkah dalam program disebut instruksi atau instruksi. Oleh karena itu, program terdiri dari serangkaian instruksi. Ketika sebuah instruksi dieksekusi, operasi yang sesuai dengan instruksi itu dilakukan oleh komputer. Secara umum, komputer terdiri dari empat komponen utama, yaitu perangkat input, perangkat output, unit pemrosesan utama, dan memori.
Central Processing Unit (CPU) adalah "otak" dari komputer, yang berfungsi untuk melakukan operasi dasar seperti operasi perbandingan, operasi komputasi, operasi baca, dan operasi tulis. Memori merupakan komponen yang berfungsi untuk mengingat atau mengingat untuk mengingat. Apa yang disimpan dalam memori adalah program (berisi operasi yang akan dilakukan oleh CPU) dan data atau informasi (sesuatu proses operasi).

Perangkat masukan dan keluaran (I/O devices) adalah perangkat yang memasukkan data atau program ke dalam memori dan merupakan alat yang digunakan oleh komputer untuk mengkomunikasikan hasil aktivitasnya. Contoh perangkat input termasuk keyboard, pemindai, dan cakram. Contoh perangkat output adalah display (monitor), printer (printer) dan disc. Mekanisme kerja keempat komponen di atas dapat dijelaskan sebagai berikut.

Program ini awalnya disimpan dalam memori komputer. Ketika program dijalankan (execute), semua instruksi yang telah disimpan di memori dikirim ke CPU. CPU melakukan operasi sesuai dengan instruksi ini. Ketika suatu operasi membutuhkan data, data dibaca dari perangkat input, disimpan dalam memori, dan kemudian dikirim ke CPU untuk operasi yang membutuhkannya. Ketika proses menghasilkan output atau informasi, output disimpan dalam memori, kemudian memori menulis output ke perangkat output (misalnya, menampilkannya di layar monitor). 


\section{Input dan Output}

Algoritma memiliki 5 ciri pokok yaitu:

a. Finitenes algoritma selalu berakhir setelah melalukan beberapa langkah

b. Definitenes setiap langkah harus terdefenisi secara logis

c. Suatu algoritma dapat memiliki input satu atau lebih juga dapat tidak memiliki input

d. Suatu algoritma paling sedikit memiliki satu output

e. Suatu algoritma diharapkan efektif setiap langkah hendak dibuat sederhana.

\section{Input}

Meminta data yang diperlukan dari user. Sebagai contoh dalam menghitung sebuah keliling lingkaran tentu diperlukan data berupa nilai jari - jari dan nilai phi. Data yang diinputkan berupa integer, real, char atau string. Dalam algoritma programmer memikirkan user menginput data berupa mouse, keyboard, scanner atau yang lain sebagainya. Programmer tidak perlu memikirkan masalah tampilan saat penginputan berlangs'ung

\section{Output}

Mencetak informasi yang dihasilkan oleh algoritma contohnya dalam menghitung luas persegi, hasil akhir yang diinginkan adalah luas persegi dengan kata lain memiliki satu output yaitu luas persegi. Bentuk penulisannya write dimana data berupa data konstan, nama konstanta, ekspresi, suatu variabel.Dalam algoritma programmer tidak mempermasalahkan data yang akan di cetak karena merupakan masalah dari pemograman. Programmer juga tidak mempermasalahkan format data yang di cetak.

\section{KESIMPULAN}

Pemakaian komputer sangat pesat sejalan dengan teknologi dari computer sendiri.Dimanfaatkan diberbagai bidang contohnya dibidang industry, perdagangan, pendidikan, pemerintahan, ilmu pengetahuan eksakta juga social budaya. Komputer merupakan sebuah alat yang sangat canggih dengan serangkaian perintah manusia untuk menyelesaikan sebuah permasalahan yang muncul secara cepat, tepat, akurat. penyelesaian masalah disebut dengan program,agar program dapat diselesaikan harus menggunakan bahasa yang dapat dipahami oleh komputer yang disebut dengan bahasa pemrograman. Pemrograman adalah proses mengimplementasikan algoritma dengan suatu bahasa pemrograman (Budi,2000:21.Algoritma dan pemrograman merupakan jantung pembelajaran teknik informatika.

Pemrograman memiliki tujuan memuat program untuk melakukan perhitungan sesuai dengan keinginan juga kebutuhan dari programer.Dalam penggunaan pemrograman dibutuhkan keterampilan dalam algoritma, logika,juga bahasa pemrograman. Berdasarkan pendapat Sutedjo 2000:21 pemrograman ialah suatu proses mengimplementasikan algoritma menggunakan sebuah bahasa pemrograman. 
pemrograman dapat juga diartikan proses menulis,menguji, memperbaiki juga memelihara untuk membangun program komputer yang tertulis dalam bentuk bahasa pemrograman.

Secara bahasa logika berasal dari Yunani yakni Logos mengartikan ilmu.logika adalah ilmu yang mengajarkan bagaimana cara berpikir secara kritis untuk bisa melakukan sesuatu mencapai tujuan yang pasti.

\section{DAFTAR BACAAN}

Munir,(2016) Kontribusi matematika dalam TIK

Irwan. 15 Desember 2015,"Jurnal Algoritma dan

pemrograman".http://tkjpnup.blogspot.co.id/ 2013/12/jurnal-algoritma-

pemrograman.html

Budiman, Edy. "Belajar Dasar Algoritma dan Pemograman”. Samarinda. 2015.

Fathoni Muhammad dan Saniman. "Pengantar Algoritma dan Pemograman". Jurnal SAINTIKOM. Vol 4. No 1. 2008.

Chandrawati,sri rahayu.2010.pemanfaatan e-erlening dalam pembelajaran.No 2 vol. 8 . ;Http://jurnal.untan.ac.id/

A.S,R. (2018). LOGIKA ALGORITMA dan PEMOGRAMAN DASAR. BANDUNG: MODULA.

Mahalisa Galih" WEB Developer Informasi berbasis aaalgoritma dan pemrograman "Teknologi, Vol,11,2020
Maulana, Gun Gun. 2017. Pembelajaran Dasar Algoritma dan Pemrograman Menggunakan El-Goritma Berbasis Web. Jurnal Teknik Mesin. Vol. 6, No.2

Isroqmi, Asnurul. 2017. Kemampuan Mahasiwa Memahami Logika Pemrograman Komputer Melalui Algoritma. Jurnal Pendidikan Matematika. Vol. 2, No.2

Pranata, A. 2005. Algoritma dan Pemrograman. Yogyakarta: Penerbit Graha Ilmu.

Daru, Kusuma Purba. " Algoritma dan Pemrograman". Deepublish 2020.

Marga Retta, Allen, dkk. "Pengaruh Penerapan Algoritma terhadap Pembelajaran Pemrograman Komputer". Pendidikan Matematika, Universitas PGRI Palembang. Volume 2 No.2 Hal 126-135.

Ar Rasyid Haris " Pengembangan Sistem Kuis Algoritma pemrograman berbasis web", Vol 3, 2020. 